\title{
Re-thinking humanism as a guiding philosophy for education: a critical reflection on Ethiopian higher educat0ion institutions
}

\author{
Sisay Tamrat ${ }^{1}$ \\ Published online: 14 May 2020 \\ (C) The Author(s) 2020
}

\begin{abstract}
This paper aims to articulate and clarify the very essence of humanism and then contextualize it to the Ethiopian context. In this case, I believe that a humanistic philosophy for education is the best approach that helps students become holistic beings - citizens who are both morally/intellectually and economically capable, autonomous, critical and responsible. Students of Ethiopian Higher Education Institutions (EHEIs), however, are characterized by a dearth of humanistic elements for education. They are marred with intellectual and moral decadence. The methodology is qualitative for it largely depends on reviewing literatures and policy documents on the issue. The upshot of this paper is that the ideals of humanism in education is not an extra - icing on the cake- it is an essential tool that would clean the academic environment from the entrenched overall moral and intellectual decay permeating EHEIs.
\end{abstract}

Keywords Humanism $\cdot$ Higher education $\cdot$ Human dignity $\cdot$ Freedom, intellectual decadence $\cdot$ Moral sickness

\section{Introduction}

It is very difficult if not impossible to have a universal approach to education that is applied in schools. This difficulty is a direct reflection of the recognition of the variations and differences of both the learner and educator. The problem is also related to the absence of a universal underpinning to the definition and purpose of education itself, for education has been defined in many ways, at different times, by different authors.

Sisay Tamrat

sisaytamirat038@gmail.com

1 Faculty of Social Sciences, Department of Political Science and International Studies, Bahir Dar University, Bahir Dar, Ethiopia 
For Socrates, Jaspers (1959) declaims, for instance, education is like midwifery in which students are assisted to give birth to their abilities and talents (p. 50). Kant, on the other hand, Dewey (2004) argues, defines education as the process by which man becomes man (p. 102). Both [Kant and Socrates] underpinnings, though seems different, convey a virtually similar meaning since 'man becomes a man' when the learner is assisted or empowered to develop or give birth to his/her talents and abilities. So the difference between these two interpretations is only a matter of sequence - man becomes a man after he is empowered to give birth to his natural talents and abilities.

Notwithstanding the differences writers, viz. Rousseau, believes that education is nothing other than a means or process whereby the learner would 'realize his/her destiny' and 'achieve his/her full humanity' so that he/she will be equipped to fit the constantly changing and dynamic environment. Put differently, through education learners will grow in to a worthy citizen not only to themselves but also to others (Monteiro n.d., p. 16).

Realizing such a noble ideal, however, cannot be imagined in a vacuum. It is imperative rather to choose educational philosophy which is flexible and that best fits both the context (after all "to consider educational issues independent of the larger cultural, social, and economic context involves either serious ignorance or cynical, if not criminal, deception" (Aloni 2014, p. 4)) and uniqueness (for "education without true appreciation for the uniqueness of each and every individual is an empty endeavor" (Zucca-Scott 2010, p. 32)) of both the learners and educators.

An approach to education that best fits to and then could produce worthy citizens who could realize their full humanity, I argue, is by introducing (re-thinking) humanism as a philosophy for education to our educational system especially to Higher Education Institutions (HEIs). Choosing humanism as an approach to education however necessitates, first, understanding and clarifying the very nature and philosophy of what humanism is meant.

According to Copson (2015), humanism has been variously termed by different authors, among others, as a 'worldview', an 'approach to life', a 'life stance', an 'attitude', a 'way of life', and a 'meaning frame' (p. 5). All these variations and multiplication of nomenclature would imply the absence of consensus regarding the question what humanism is meant. As Wright (1977) has put it, this question 'has no univocal answer' and its underpinning 'is not a historical constant' for it is rather 'perpetually open' (p. 6).

The openness of the question, as Von Wright continued to argue, is closely related to the openness of the question what man is meant. Stated otherwise, the openness of the question what humanism is- a direct derivative of the openness of the question 'what is man's place in the world - order?' Since 'man has no fixed place in the order of things' and since 'man is free to choose his nature' (ibid), finding a universal definition for humanism has become a difficult, if not impossible, task.

Notwithstanding lack of universal underpinning of humanism, we can at least mention some of the common elements given by scholars of humanism. Among others, humanism gives primacy for human dignity, autonomy and respect for cultures over any other set of values. It gives more emphasis on the importance of the 'inner world of the learner'. Humanism focus on the 'pursuit of the whole person' - it targets not only man's biological desires such as material welfare and economic success but also strives to realize the 
development of his spiritual, emotional, psychological, moral and intellectual wellbeing.

If we appraise EHEIs by standing on this humanistic ideal, we can argue that the practice is almost antithetical to what we ought to be. This is because the Ethiopian education system practically, though not theoretically, focuses on one-sided aspects of man - a materialistic conception of man and the universe in general - which in turn undermines the inner aspects of the learner.

This paper, therefore, focuses on a critical reflection to such and other related problems affecting EHEIs. It attempts to choose and then applies an approach to education that could address this problem.

\section{The Telos of higher education institutions ${ }^{1}$ and humanism}

It is not naïve to relate and/or derive the telos of HEIs from the telos of education in general. Accordingly, the purpose of HE, Forbes (1999) argues, is nothing other than 'the cultivation of the total human being' or 'the awakening of intelligence' or 'a capacity to discover truth' and 'live with certain goodness' (p. 5-6); or it is 'the pursuit of truth and the provision of intellectual and moral leadership" (Biggs 2002, p. 22); or it is "to have an open mind" (Jaspers 1959, p.68); it "produces a gentle man" - a person who has a 'cultivated intellect', a 'delicate taste', a candid, equitable, dispassionate mind, a noble and courteous bearing in the conduct of life (Newman 1852, p. 146). All these ideals, directly or indirectly, are integral of humanistic education.

According to Wright (1977), the term 'humanism' (Humanismus) seems to be an early nineteenth century German invention. It was in origin used for referring to the movement in literature and scholarship (p.5). Historically, humanistic education, Aloni (2014) argues, is traced back to the times of classical Athens with its central notion of Paideia, a few centuries later to the times of ancient Rome with it central notion of Humanitas, then the Renaissance's Humanists, and in the early nineteenth century it was the German educator Neithammer who coined the concept of Humanism as indicating liberal education ${ }^{2}$ toward full humanity (p.1).

Although there are different definitions given to the term, the most common understanding given by most scholars (Mohammad Khatib 2013, Copson 2015, Von Wright 1977, \& Aloni 2014, Veiga 2015), include an 'attitude to life' or 'attitude to mind' that focus on man's dignity, autonomy and the valuing of human beings and human culture. Scholars of humanism have defined humanism as the 'pursuit of the whole person' or 'full human being' in skills, abilities, moral development and psychological wellbeing.

According to Aloni (2014), as it is quoted in Khatib et al. (2013), it is crucial for humanistic education to prioritize the value of human dignity over any other economic, religious, nationalistic or ideological set of values (p. 45). Humanistic approach therefore emphasizes the importance of the 'inner world of the learner' and places

\footnotetext{
${ }^{1}$ I have used the term Higher Education Institutions (HEIs) to refer the broad sense interpretation which is equivalent to a university though in a strict sense these two terms represent two different things.

2 Traditionally, the term liberal education and humanistic education can be used interchangeably though the two do not refer the same thing strictly speaking.
} 
the individual's thought, emotions and feelings at the forefront of all human development.

Since humanistic education focus on cultivating both the intellectual and emotional dimensions of the learner, the end of education is the same as the 'end of psychotherapy': making a fully functioning person (ibid). According to Aloni (2014), humanistic education is used to refer a variety of educational theories and practices that are devoted to the world-view and ethical code of humanism; that is, positing the enhancement of human development, well-being, and dignity as the ultimate end of all human thought and action (p.1).

As it has been quoted in Copson (2015), 'we are both inside nature and outside of it'. In other words, human beings are 'both objects of nature' and 'subjects that can shape their fate'. They are both biological and conscious beings with purpose and agency, that is, traits the possession of which allow us to design ways of breaking the constraints of biological and physical laws. The core of humanity is thus our reflexiveness - we do have the ability and need to 'take ourselves as the objects of our own inquiry' (p. 10) we dare to know and interrogate who we are - a very crucial ideal that enable students to be not only critical of other things/beings but also their own self.

This saying supports, but not identical with, the arguments of Sartre, an existentialist philosopher, who says "man is the maker of his own fate" (Bhardwaj 2014, p. 13) and Socratic tradition of the 'pedagogy of questioning' in education that culminate in the virtue of 'know thyself' or knowing the self - the highest virtue of man's endeavor that creates, Zucca-Scott (2010) relates, opportunities for all students to be themselves and help students find out who they are and what their talents are as individuals (p. 36). The Socratic motto of 'know thyself', I believe, is not a simplistic and egoistic attitude towards the self because it has a benevolent approach towards others, ${ }^{3}$ too for, as it has been quoted in Copson (2015), it is in proportion to the development of one's individuality, each person becomes more valuable to himself, and is therefore capable of being more valuable to others (p. 16).

One important aspect of humanistic education is human freedom - Bhardwaj (2014), echoing the words of Sartre, states that 'man is born free' (p.13) for it advocates his independence of received authority in matters of truth and it, Wright (1977) stated, is only through a process of educating himself can man attain to true freedom (p.18). Man, I strongly argue, is genuinely free when he is considerate of not only his own interest but also the interest of others.

It implies that the actions of a properly free man cannot or should not have undesirable consequence not only to himself but also for his fellow human beings. Therefore, a man realizes his freedom only when his actions, including the outcomes of his action, are compatible with the need and interest of others. From this, we can understand that real freedom is not selfish but is benevolent if not totally selfless.

Although humanists have often been 'accused of utopianism' for imagining 'a vision of high standards of living', all contemporary humanistic educators, Aloni (2014) states, share a commitment to humanize their students in a spirit of intellectual freedom,

\footnotetext{
${ }^{3}$ Plato in his theory of education depicts one of the freed man who could, first, break the bondage in the cave and get out of the cave. This is because, for Plato, this man, in addition to liberating himself, has to get back to the cave and assist others to break their bondage and then withdraw out of the cave - helping others liberate from both self-imposed or other forms of tutelage.
} 
moral autonomy, and pluralistic democracy. Also, they aim to provide the kind of education that, first, liberates their students from the fetters of ignorance, caprice, prejudice, alienation, and false-consciousness, and, secondly, empowers them to actualize their human potentialities and lead autonomous, full, and fulfilling human lives (p. 2).

\section{Humanism and Ethiopian Higher Education Institutions (EHEls)}

There is a truth in saying that "every educational system has a moral goal that it tries to attain and that informs its curriculum. It wants to produce a certain kind of human being...." (Bloom 1987; p. 26). In some nations, the purpose is to produce morally responsible persons, in others technicians, still in others hard workers. The question that is worth mentioning here is what the moral goal of the Ethiopian educational system is in general and EHEIs in particular?

To address this question, it is imperative to mention the overall mission statements of Ethiopian universities. The goals of higher education in Ethiopia are to "prepare knowledgeable, Skilled, and attitudinally mature graduates in numbers with a demand-based proportional balance of fields and disciplines so that the country shall become internationally competitive" (Negarit Gazeta 2009, p. 4979). Theoretically speaking, this objective seems promising while practically it has been narrowed down to fit only the economic rationality - realizing the national vision of becoming a middle-income country by 2015 (FDRE 2015, p. 11). The major instruments used to achieve this national vision is by applying "science, technology and innovation" (ibid, p. 11) or through "technology transfer and innovation" (Negarit Gazeta 2009, p. 4991).

There is nothing intrinsically wrong to give priority for science and technology and bringing economic development. The problem, however, occurs when the social sciences and humanities (disciplines which are thought to be tools for the development of the inner-aspects of the learner such as the moral, spiritual and emotional) are given minimal attention, in the name of bringing economic development, by introducing the policy of "70:30 discipline mix"(MOE 2018, P. 56)- 70\% of new university entrants are expected to join in the science, technology and the remaining $30 \%$ entrants join social sciences and humanities.

Even if we believe that realizing the economic aspiration of becoming a middleincome country, by giving priority to the science and technology, is of paramount significance, it could not be materialized in a situation when most of the students who joined higher education institutions with results below the $50 \%$ threshold in the higher education entrance examinations (Ministry of Education 2015, p. 24). What is even worse is when in physics, a basis for engineering studies, students' results are extremely low" (ibid). Also, research shows that students who managed to pass the General Secondary School Leaving Examination could not read and write properly in English language - which is a medium of instruction in higher learning institution in Ethiopia" (Ministry of Education 2018, p. 53).

Also, the overall mission statement of Ethiopian universities is - "producing (in a cost effective and result oriented manner) quality human resource in disciplines relevant for the socio-economic development of Ethiopia, as well as undertaking relevant and quality research" (Yizengaw 2003, p.7). Practically, such a motto, though 
not intrinsically bad, gives more emphasis to the material aspects of education by disregarding the cardinal aspects of the ideal of humanistic education - achieving full humanity - both inner and physical aspects of man, moral and intellectual excellence, human dignity, freedom and autonomy, critical thinking, self-knowledge, independent decision making, the values of being considerate to the interest of others.

Hence, the root of the problem for Ethiopian universities lies in the educational philosophy - a philosophy virtually guided by what Veiga (2015) called a 'short-sighted materialistic conception of the universe in general and the human being in particular' a view which gives primacy to 'material welfare', 'career progression' and 'social competition'. The ramification of such conception is that since 'there is no other purpose in life'; economic success becomes the center of societal and individual striving (p. 2).

To this end, being educated and knowing is measured to the degree that results in a good job and better payment. It is, therefore, imperative to go to school and university for it is the 'springboard to a well-paid profession' and 'high social standing' - a dangerous watershed in eroding the production of a fully functioning person - a person who is both emotionally/ intellectually and physically fit. This one-sided approach to education thus undermine values such as integrity to the truth, self and others, concern for the public good, human dignity, intellectual excellence and critical thinking.

The problem lies, to be more precise, not so much in the fact that there is a striving for better general conditions of sustenance and comfort, but rather, that when this thinking and practice is taken as the only goal of man's life - it has serious social and existential implications. The implication is that the 'expanded views of man' such as the spiritual and inner dimensions of the learner would be undermined to a significant degree. The purpose of humanistic education, however, is to produce citizens who are worthy and humane - a virtuous man who, Aloni (2014) relates, manifests holistic integration of sentiment with reason and of personal interest with the common good (p. $3)$.

Moreover, EHEIs do not live up to the aforementioned standard for they are permeated with various intricately interrelated problems that are antithetical to the commonly known humanistic ideals. The academic environment across EHEIs is virtually characterized by a gradual erosion of integrity neither to the self nor to others nor to truth, lack of principled ways of thinking, a practice of confusing personal ego and self-interest with the public interest, having limited concern for societal interest (the truism, however, as it is quoted in Altbach (2008), is that when universities cease to be engaged with society and with the emerging scientific and political developments of an era, they tend to be moribund (p. 8)), intellectual opportunism, a focus on polarized and irreconcilable thinking which does not even allow the 'Golden Mean', intellectual and moral decadence, etc.

Man, according to Von Wright (1977), is free to choose his nature - he has the power to degenerate in to, on the one hand, the 'lower forms of life' which is brutish, and on the other, to be reborn into the 'higher forms' which is divine. It means, man is granted to be whatever he wills to be. To him, he is given 'the seeds of all kinds and the germs of every way of life' (p. 6-7). From this premise, one can easily infer that it is imperative to choose the 'seeds of all kinds' (but not to the 'germs of every way of life') and then to reborn in to 'the higher forms of being' (but not to the lower forms of life' and become brutish) and become divine or virtuous. 
If we appraise EHEIs against this yardstick, practically we are virtually inclined to choose or experience the undesirable one - preferring the 'germs of every way of life' and become brutish. For instance, although Ethiopian intellectuals are capable of searching the truth, they lack the willingness to be loyal to it by focusing rather on bending, shaping and re-shaping the truth to fit to their own narrow and short-term political, social or political whim. As a result, today's EHEIs have become repositories where wild ideas and practices germinate. ${ }^{4}$

Though it is a truism that "knowledge opens many doors with endless possibilities" (M.W.Bevel 2008, p. 11), the fact in EHEIs is antithetical to this golden ideal for much of the problems facing our people today are, directly or indirectly, related to the educated sections - became part of the cause of Ethiopia's problems instead of solving it. A notable example is the situation of the current over all political, economic and social environment in Ethiopia - people in Ethiopia are living in a virtually uncertain or unsafe condition where ethnic based harassment and displacement, killings, anxiety and insecurity presides over the fundamental human values of fraternity, equality, law, order and justice.

Generally, the ideals of humanism in education, I believe, is not an extra icing on the cake- it is an essential part of mankind that help live a good life - a life of flourishing and it is imperative to implement this philosophy to the Ethiopian context. It is an approach, I believe, that could clean the academic environment from the entrenched overall moral and intellectual decay permeating EHEIs.

\section{Conclusion}

Man, by borrowing the ideas of Sartre, is condemned to be free. This freedom, I believe, is not given in vain but used to achieve a certain purpose - the most crucial purpose of mankind. It is given to realize itself (freedom) to the best of its quality. In other words, man is born free to realize his own freedom to the finest. And this freedom, in turn has another telos to be achieved - to change the constantly changing nature to the best of its quality.

This is because man is not only a biological being (object of nature) he is also a conscious being (subject of nature) who can play an active role in facilitating the change including himself. As a conscious, reflexive and active subject, he facilitates the changing nature - to the positive or to the negative - to the best or worst of it - to the virtuous or vicious of it. Also as an object, man is part and parcel of nature that is constantly changing.

Obviously, no one needs the bad or evil outcomes to happen. What is expected of the conscious and active man is to guide or assist nature produce outcomes that are desirable and good to mankind in general. The role of man therefore is to prevent nature including man himself from corrupting to the worst end that produces results which are undesirable, bad and vicious to mankind.

\footnotetext{
${ }^{4}$ In principle HEIs are places where there is a free debate and discussion of ideas without discrimination. Also, HEIs are supposed to be the center of excellence of different types and are ought to be the model both intellectually and morally. Antithetical to these cardinal noble ideal, Ethiopian HEIs have become incubators of conflict of different types - religious, ethnic or based on other sectarian arrangements. Virtually all wild and inhuman ideas and practices first originate at the HEIs and then disseminate to the larger population.
} 
This does not mean that bad things (such as greed, injustice, conflict, war, corruption, etc.) could not happen as a result of the actions of a free agent who is man himself. Of course undesirable things could occur because of man's conscious or unconscious action. And, these bad outcomes, I argue, are the results of the actions of man who is not properly free. A free man, I believe, is someone who would use his freedom and talents to produce the finest but not the worst of outcomes.

Also, since a free man is considerate of not only his interest but also the interest of others, his/her actions couldn't or shouldn't have undesirable consequence not only to himself but also for his fellow human beings. Hence, freedom is not selfish but is benevolent if not totally selfless. Freedom, in turn, could be realized by applying a proper educational philosophy that would produce knowledge which liberates mankind from the fetters of ignorance, false consciousness, prejudice, injustice, immorality and vices of all types. Stated other ways, proper education and the corresponding knowledge should not cause problems both to the self and others rather it has to be used to solve societal problems.

The upshot of this philosophical analysis or premise is that if we have to produce not mere humans but graduates who are humane, we have to implement an approach to education, the philosophy of humanism, that best match this purpose. This is because humanism targets producing graduates, not mere graduates, who are knowledgeable and are capable of liberating, first, themselves from ignorance, irrationality, prejudice, alienation and false consciousness; and secondly, help others do the same.

Due to this reason the approach I am advocating, I can say, is not a mere egoistic philosophy rather it incorporates a benevolent attitude towards others. Man's endeavor if it has to be called genuine, it has to transcend the self (self-gratification) to the extent of addressing the interests of others. After all, we are not the centers of this universe as our life matters to us the life of others matters too.

The academic environment in EHEIs, however, is virtually marred by problems which are antithetical to the ideals of humanism. Among others, the education system is dominated mainly with a materialist conception of both the universe and man - it equates knowledge and knowing with economic success and economic wellbeing - a watershed that endangers the excellence of the inner aspects of the learner such as emotional, psychological, moral, intellectual and spiritual aspects.

Also, there are symptoms of moral and intellectual decadence, intellectual opportunism, absence of intellectual and moral responsibility, lack of integrity to truth, self and others, a gradual erosion of critical thinking and dearth of interest for others including confusing personal interest with the interest of others.

Lastly, the ideals of humanism in education, I believe, is not an extra icing on the cake- it is an essential part of mankind that help live a good life - a life of flourishing and it is imperative to implement this philosophy to the Ethiopian context. It is an approach, I believe, that would polish the academic environment from the entrenched overall moral and intellectual decay permeating EHEIs.

Open Access This article is licensed under a Creative Commons Attribution 4.0 International License, which permits use, sharing, adaptation, distribution and reproduction in any medium or format, as long as you give appropriate credit to the original author(s) and the source, provide a link to the Creative Commons licence, and indicate if changes were made. The images or other third party material in this article are included in the article's Creative Commons licence, unless indicated otherwise in a credit line to the material. If material is not included in the article's Creative Commons licence and your intended use is not permitted by statutory 
regulation or exceeds the permitted use, you will need to obtain permission directly from the copyright holder. To view a copy of this licence, visit http://creativecommons.org/licenses/by/4.0/.

\section{References}

Aloni, N. (2014). Humanistic education. Encyclopaedia of Educational Philosophy and Theory, 1-5.

Altbach, P. 2008. The complex roles of universities in the periods of globalization. Higher Education in The World 3: 5-14.

Bevel, M. W. (2008). Empathy: A difficult journey through public education in 2008. Journal of Philosophy and History of Education, 11-15.

Bhardwaj, B. (2014). Humanism in Sartre's philosophy. International Journal of Humanities and Social Science Invention, 12.

Biggs, J. 2002. The Subverstion of Australian universities. In To the limits of Acceptablity: Political control of higher education, ed. W. Bostock, 19-40. Wollongog: Fund for Intelectual Dissent.

Bloom, A. 1987. The closing of the American mind: How higher Educationhas failed democracy and impoverished the soul of Today's students. New York: Simon Schuster INC..

Copson, A. (2015). Handbook of humanism. John Wiley \& Sons, Ltd.

Dewey, J. 2004. Democracy and education: An introduction to the philosophy of education. Delhi: Aakar Books.

FDRE. 2015. Education sector development Programme V [ESDP V]. Addis Ababa: Federal Ministry of Education.

Forbes, S. H. (1999). Freedom and Education. A paper presented at Brockwood Park Conference on Freedom and Education on 10th October 1999.

Gazeta, F.N. 2009. Higher education proclamation. Addis Ababa: FDRE.

Jaspers, K. 1959. The idea of the University. Boston: Beacon Press.

Khatib, M., Sarem, S. N., \& Hamidi, H. (2013). Humanistic Education: Concerns, Implications and Applications. Journal of Language Teaching \& Research, 4(1).

Ministry of Education. (2015). Education Sector Development Programme V [ESDP V]. Addis Ababa : Federal Ministry of Education.

Ministry of Education. (2018). Ethiopian Education Developmnt Roadmap. Addis Ababa: Education Strategy Center (ESC).

MOE. 2018. Ethiopian education Development roadmap. Education Strategy Center (ESC): Addis Ababa.

Mohammad Khatib, S. N. (2013). Humanistic education: Concerns, implications and applications. Journal of Language Teaching and Research, 45-51.

Monteiro, T. (n.d.). Rouseau's Concept of Education. 1-45.

Newman, J. H. (1852). The idea of a university defined and illustrated: In Nine discourses delivered to the Catholics of Dublin.

Veiga, M. D. (2015). Revisiting humanism as guiding principle for education: An excursion in to Waldorf Pedagogy. 19-32.

Wright, G. H. (1977). What is humanism? A Volume of Lindley Lectures, 1-27.

Yizengaw, T. (2003). Transformations in higher education: Experiences with reform and expansion in the Ethiopian higher education system. Improving Tertiary Education in Sub - Sahran Africa: Things That Work, 1-18.

Zucca-Scott, L. 2010. Know thyself: The importance of humanism in education. International Education 40: $32-38$.

Publisher's note Springer Nature remains neutral with regard to jurisdictional claims in published maps and institutional affiliations. 